\title{
Gastric Cancer pN3 TNM Finding v8
}

National Cancer Institute

\section{Source}

National Cancer Institute. Gastric Cancer pN3 TNM Finding v8. NCI Thesaurus. Code C133622.

Gastric cancer with metastasis in seven or more regional lymph nodes. (from AJCC 8th Ed.) 